\title{
Sponges as agents of biological disturbance
}

\author{
James J. Bell* \\ Centre for Marine Environmental and Economic Research, School of Biological Sciences, Victoria University of Wellington, \\ PO Box 600, Wellington 6140, New Zealand
}

\begin{abstract}
Sponges have diverse roles in marine ecosystems and here I describe a newly identified functional role for sponges as agents of biological disturbance. Sponges are thought to be one of the top spatial competitors in benthic environments, and in temperate regions periods of increased space acquisition and successful spatial competition (overgrowth) during positive sponge growth periods are often followed by seasonally driven periods of space loss. I investigated the potential role of 2 intertidal sponges (Halichondria panicea and Hymeniacidon perlevis) as agents of biological disturbance. The population dynamics and competitive interactions of these 2 sponge species were measured at 2 sites on the coast of west Wales over a 2 yr period. Both species were common on the lower shore at the 2 study sites covering up to $18 \%$ of the available rocky substrate (both species combined) depending on the sampling date. Both sponges effectively overgrew most organisms they encountered during growth periods, but the new space they occupied was mostly released as tissue retraction occurred during the autumn and winter months. Since sponge re-growth in the spring and summer did not necessarily occupy the same area of rock as the previous year, weaker competitors were able to recruit to the newly available space (ca. 3 to $4 \%$ of the lower shore area per year) and persist over time. Given the widespread abundance of sponges in intertidal and subtidal environments, and the increasing evidence for only short-term temporal stability in many sponge assemblages, this example demonstrates that many sponges may be important biological disturbance agents in marine communities.
\end{abstract}

KEY WORDS: Sponge $\cdot$ Biological disturbance $\cdot$ Temporal variability $\cdot$ Competition

\section{INTRODUCTION}

Sponges are an important component of hard substratum low intertidal and subtidal communities across temperate, tropical and polar environments. Sponges fulfill a wide range of ecological roles and therefore make an important contribution to ecosystem functioning (Diaz \& Rützler 2001, Wulff 2001, Bell 2007a, 2008). Many of the functional roles that sponges perform have been well documented, including benthopelagic coupling (Goreau \& Hartman 1966, Reiswig 1971), enhancement of coral survival by preventing the access of excavating organisms to coral skeletons (Goreau \& Hartman 1966), mediating the regeneration of physically damaged reefs by temporarily stabilising carbonate rubble (Wulff \& Buss 1979), bioerosion (Rützler 1975), nutrient recycling (Corredor et al. 1988), facilitating primary production (Wilkinson 1983), habitat provision (Ribeiro et al. 2003) and acting as a food source for other organisms (Wulff 2006a). Despite the recognition that sponges are important to coral reef systems, far less is known about their roles in temperate and polar habitats. Furthermore, in addition to the roles described above there are other functional roles that sponges perform that have been comparatively poorly studied even though they have the potential to influence community dynamics, population structuring and ecosystem functioning.

In temperate regions sponges often occupy a large amount of primary space, and although there is a paucity of information on their ecological roles, sponges are probably important in the provision of habitat, bentho-pelagic coupling and spatial competition (see Bell 2008 for recent review; Bell \& Barnes 
2003). Of particular interest is spatial competition, as although sponges form a range of mutualistic relationships, they are often one of the top inter-phyletic spatial competitors (e.g. Bell \& Barnes 2003, Wulff 2006a). This means sponges have the potential to influence community structure by out-competing other organisms. Unfortunately, there are still comparatively few studies of sponge spatial competition in temperate regions, compared with tropical systems. Since sponges rarely form mono-specific stands and therefore co-exist with a range of other organisms, mechanisms must exist to prevent sponges from monopolising space. Sponges, being soft-bodied organisms, may show greater susceptibility to physical damage from either biological or physical forces than other organisms, which may release organisms from competitive interactions with sponges. Alternatively, organisms may be released from competition with sponges during periods of sponge tissue retraction. A number of temperate sponges have been reported to exhibit seasonally correlated growth dynamics (e.g. Stone 1970, Barthel 1989) where the area occupied by sponges and/or biomass decreases during autumn and winter. Such decreases not only have the potential to release organisms from competition with sponges, but can also create space that can be subsequently colonised by competitively inferior organisms. The mechanism behind seasonal retraction of sponge tissue is poorly understood, and it is unknown if this is an active process controlled by the sponge (e.g. controlled tissue retraction as result of reduced food or temperature) or a passive process that the sponge has no control over (e.g. from increased erosion/wave action).

Space is a fundamental limiting resource in most rocky benthic marine habitats, meaning that the majority of organisms will enter into either competitive or cooperative interactions (Paine 1974). For the majority of benthic communities multiple biological and physical processes are thought to operate to prevent the monopolisation of space by any superior competitor, with maximum diversity theoretically occurring at moderate levels of disturbance, according to the intermediate disturbance hypothesis (IDH; Paine 1974, Connell 1978, Sousa 1979). Importantly, not all studies of the IDH have reported such relationships (e.g. Bell \& Carballo 2008). Disturbance may prevent space monopolisation by competitively dominant species, which has predominately been considered to be the result of multiple physical processes (e.g. wave forces, sedimentation and current flow), although biological processes have also been implicated. Grazing and predation have been considered to be the primary biological disturbance agents (Paine 1974, Connell 1978, Ayling 1981), but other agents also exist such as disease (Ayling 1981) and growth/retraction processes.
Since sponges are (1) abundant in many intertidal and shallow subtidal benthic habitats, (2) one of the top spatial competitors and (3) often subject to seasonal fluctuations in the space they occupy, I hypothesise that sponges have the potential to act as a biological disturbance agent over short temporal scales. Therefore, sponge population variability has the potential to be a source of disturbance (seasonal space creation), and sponge population dynamics may be an important structuring process for benthic communities. The importance of the space freed when sponge tissues retract will depend on whether the space created is reoccupied by the sponge in the following year. This will influence the degree to which other organisms can utilise this space. The extent to which sponges reoccupy the same space they have lost due to winter tissue regression remains unknown and is a focus of the present study.

I investigated the seasonal variability in spatial occupation of the common temperate intertidal sponges, Halichondria panicea (Pallas, 1976) and Hymeniacidon perlevis (Montagu, 1818) as models to examine the ecological role that sponges may play in disturbance and space creation. The growth dynamics of these species has been studied by several authors who have found seasonally correlated growth patterns with increased space occupation in the spring and summer and subsequent reductions during autumn and winter (Stone 1970, Barthel 1989, Bell \& Barnes 2002). These species have the potential to be an important source of biological disturbance. The aims of the present study were to (1) examine the spatial dynamics of $H$. panicea and $H$. perlevis at 2 sites on the Welsh coast, (2) examine the competitive ability of $H$. panicea and $H$. perlevis, (3) determine the amount of seasonally created space released by sponges and (4) identify whether space that is released during tissue contraction periods is used by the same sponge in the following year or whether colonising organisms can make use of this space.

\section{MATERIALS AND METHODS}

Study sites. The present study was conducted at 2 rocky shore sites on the west coast of Wales, north of Aberystwyth. The first site was located at the south end of Clarach Beach $\left(52^{\circ} 25^{\prime} 55.61^{\prime \prime} \mathrm{N}\right.$, $\left.04^{\circ} 04^{\prime} 48.57^{\prime \prime} \mathrm{W}\right)$, while the second site was located ca. $6 \mathrm{~km}$ north of the first site $\left(52^{\circ} 28^{\prime} 47.12^{\prime \prime} \mathrm{N}\right.$, $\left.04^{\circ} 03^{\prime} 08.57^{\prime \prime} \mathrm{W}\right)$. Both sites are moderately exposed intertidal rocky areas with typical northeast Atlantic zonation patterns (Lewis 1964). The area consists of reef platforms (90 to $100 \%$ bedrock), with many small gullies and rockpools which support abundant sponge populations on the very low shore. Intertidal sponge 
richness is low, although the sponges Halichondria panicea and Hymeniacidon perlevis are abundant on the lower shore. These species generally occur on the lower shore of the 2 sites along with Ophlitaspongia seriata (Grant, 1826), although $H$. perlevis generally extends further up the shore than either $H$. panicea or O. seriata.

Surveys of sponge abundance. Surveys were conducted in January and September in 2004 and 2005 to determine the overall abundance of sponges on the lower shores of the 2 sites. The tidal height of the sampled area was ca. 0 to $0.3 \mathrm{~m}$ above the low spring tide mark, which is where the sponges are most abundant. Three haphazardly placed $25 \mathrm{~m}$ transects were laid out (perpendicular to the shoreline) at least $50 \mathrm{~m}$ apart on the low shore at spring tide. The area occupied by sponges was estimated by moving along each transect with a $1 \mathrm{~m}^{2}$ divided quadrat (25 quadrats for each transect, $\mathrm{n}=75$ in total for each site); 80 to $100 \%$ of the area sampled was considered suitable sponge habitat. For each quadrat I estimated the abundance (percentage cover) of Halichondria panicea and Hymeniacidon perlevis.

Sponge dynamics. Thirty individual sponge patches of each species were monitored bi-monthly over a 2 yr period between January 2004 and November 2005 at each site. Sponges that were selected for monitoring were all approximately the same size at the start of the monitoring period (70 to $80 \mathrm{~cm}^{2}$ for Halichondria panicea and 50 to $60 \mathrm{~cm}^{2}$ for Hymeniacidon perlevis). The surface area of each sponge was estimated monthly by taking digital photographs (with a known size scale in each photograph). The area occupied was calculated using the UTHSCSA ImageTool Version 3. Each sponge was relocated using a detailed map constructed for the study areas and digital photographs. No sponge patch selected for monitoring was closer than $1 \mathrm{~m}$ from another patch, which reduced the potential for sampling clones. Fission and fusion events occurred during the present study, although for the purpose of the present study the total area occupied by all fragments of the original sponge was combined to estimate the total area occupied/remaining for each sponge. The sponges (both species) used for monitoring all had cushion morphologies (ca. 5 to $10 \mathrm{~mm}$ thick), which are characteristic of this region.

Spatial interactions. I examined the spatial interactions of the 30 sponges of each species that were monitored (at each site) for population dynamics. The interactions were recorded between May and September each year when sponges increased the space they occupied. Interactions were classified as (1) 'overgrowth by the sponge' where sponge tissue overgrew a spatial competitor, including full or partial blocking of the competitors' feeding apparatus (resulting in death), (2) 'overgrowth of the sponge' where more than $5 \%$ of the sponge was overgrown and (3) 'standoff' where neither the sponge nor competitor increased the space they occupied at the expense of the other. Overgrowth of coralline algae patches were reported as successful when at least $10 \%$ of the algal patch had been overgrown.

Reoccupation of previously occupied space and settlement of new organisms. Digital photographs of each sponge specimen were used to examine the reoccupation of previously occupied space. I measured the area of rock that was occupied by each sponge in September 2004 and then how much of the same area of the same rock was still occupied in September 2005 (after tissue regression during the winter and subsequent tissue growth in the summer). This was possible by tracing digital photographs and then overlaying the sponge outlines from the different time periods. I also identified any organisms that had settled in the newly available space and examined their survival over the remainder of the observation period (until November 2005).

Statistical analysis. A balanced 3-way generalised linear model (GLM) analysis of variance (ANOVA) was used to compare the total sponge abundance (overall area occupied at the sites) between sites, seasons and years. There were 3 fully orthogonal factors in the analysis giving a $2 \times 2 \times 2$ factorial design. As a factor in the analysis, site indicated the location where sampling took place and was considered as a random factor (2 levels). Season (fixed factor) indicated when sampling took place (2 levels; January and September). Year (random factor) referred to the year that sampling took place (2 levels; 2004 and 2005). Plots were constructed to examine changes in the mean sponge patch size over time. Minitab Version 13 was used for the analysis.

\section{RESULTS}

\section{Sponge abundance and population dynamics}

A 3-way GLM ANOVA (data were square-root transformed to achieve normality; equal variance was determined using Levene's test) showed the overall abundance of sponges on the lower shore at the 2 sites differed significantly between January and September $\left(F_{1,592}<29.2, \mathrm{p}<0.05\right)$ in both years but not between years or sites $\left(F_{1,592}<1.39, \mathrm{p}>0.05\right)$. Overall sponge abundance increased from $3.2 \%( \pm \mathrm{SE}=1.1)$ cover in January to $9.1 \%( \pm \mathrm{SE}=2.1)$ cover in September for Hymeniacidon perlevis and from $4.4 \%( \pm \mathrm{SE}=1.2)$ cover in January to $9.6 \%( \pm \mathrm{SE}=2.0)$ in September for Halichondria panicea (Fig. 1). There were no significant interaction terms. 


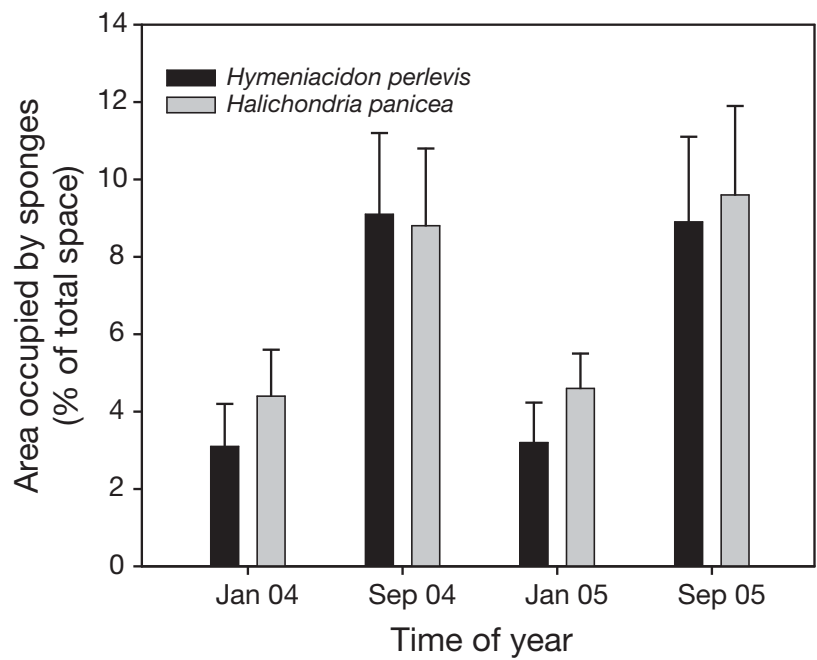

Fig. 1. Halichondria panicea and Hymeniacidon perlevis. Overall sponge abundance (\% of rock substratum occupied) for 2 sponge species at 2 sites on the west Wales coast in January and September in 2004 and 2005. Data are means (+SE) from $25 \times 1 \mathrm{~m}^{2}$ quadrats placed along $3 \times 25 \mathrm{~m}$ transects $(\mathrm{n}=$ 75 in total for each site/time interval)

The area occupied by the 30 original specimens of Halichondria panicea and Hymeniacidon perlevis monitored over the study period varied considerably through time, although patterns were similar for both species (Fig. 2; data combined for both sites). Some monitored sponges suffered complete mortality (defined as the complete loss of all sponge tissue irrespective of whether or not it had fragmented) during the study period, with 4 specimens of $H$. panicea ( 2 at each site) and 3 specimens of $H$. perlevis ( 1 at site 1 and 2 at site 2) dying over the study period. There was no apparent pattern in the mortality, although all sponges died during 2005 (Fig. 2). In all cases the mortality was very quick, and there were no signs of unusual shrinkage or disease the month before they died. The area occupied by both species increased between March and September with subsequent declines in the area occupied between September and March; there were similar patterns for both species.

\section{Spatial interactions}

Both Halichondria panicea and Hymeniacidon perlevis were aggressive spatial competitors, and both species overgrew most organisms they encountered during growth periods (Fig. 3; data combined for both sites). Both species overgrew most barnacles (predominately Semibalanus balanoides but also Chthalamus spp.), serpulids, coralline algae and bryozoans they encountered, with only a few individuals of each of

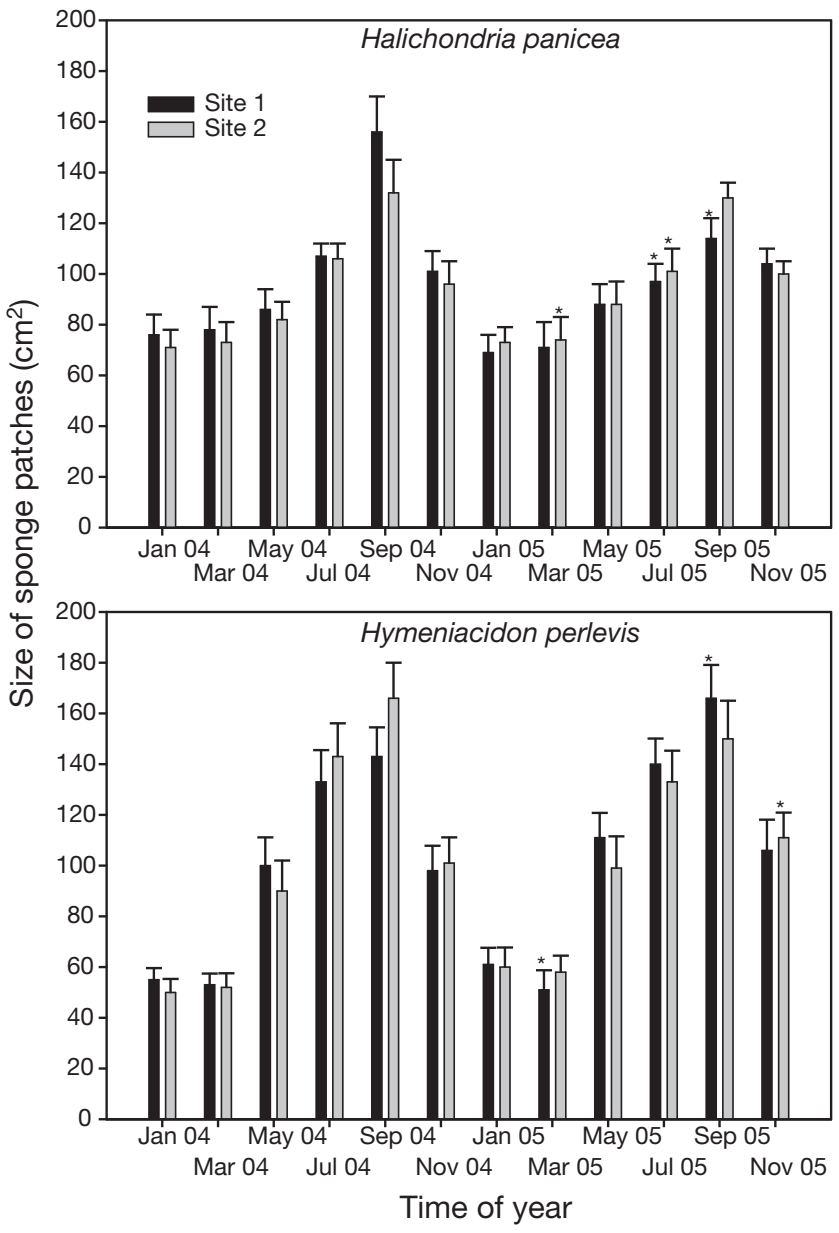

Fig. 2. Halichondria panicea and Hymeniacidon perlevis. Changes in the mean size $(+\mathrm{SE})$ of the monitored sponge patches at 2 sites over a $2 \mathrm{yr}$ period ( $\mathrm{n}=30$ for each species at each site). $\left({ }^{*}\right)$ single sponge mortality event

these groups not being overgrown; once overgrown the apertures were covered and they died. None of these species overgrew the sponges. H. panicea patches were involved in some interactions (14 in total) with $H$. perlevis, which in all cases resulted in $H$. panicea overgrowing the tissue of $H$. perlevis. In these interactions the losing sponges persisted beneath the tissue of $H$. panicea with no obvious negative impacts on either sponge. Sponges were commonly overgrown by ascidians, although in some interactions sponges were able to overgrow ascidians.

Sponges commonly interacted with macroalgae $(\mathrm{n}=$ 101 and 134 for Halichondria panicea and Hymeniacidon perlevis, respectively), although the nature of these interactions were difficult to classify as both species tended to grow around the algae or over the holdfasts and became incorporated into the sponge patch with no obvious negative or positive effects for the sponge or algae. 


\section{Reoccupation of previously occupied space}

In all cases the sponge patches that were monitored over the 2 yr period increased in size over the spring and summer months and decreased in size during autumn and winter (Fig. 2). When the actual area of rock occupied by the sponge patches was compared in 2004 and 2005, it was apparent that although sponge patches in 2005 generally grew at least as large as patches in 2004, they did not necessarily reoccupy the same specific rock space. So sponge contraction and then regrowth does not uniformly occur at the
Table 1. Hymeniacidon perlevis and Halichondria panicea. Organisms that colonised the space that became available during the contraction of sponge tissue that was not reoccupied by the sponge. The proportion of colonising organisms surviving until the end of the observation period (November 2005) is also shown

\begin{tabular}{|c|c|c|c|c|}
\hline \multirow[t]{2}{*}{ Group } & \multicolumn{2}{|c|}{ H. perlevis } & \multicolumn{2}{|c|}{$-H$. panicea -} \\
\hline & Settlers & $\begin{array}{c}\text { Proportion } \\
\text { surviving (\%) }\end{array}$ & Settlers & $\begin{array}{c}\text { Proportion } \\
\text { surviving (\%) }\end{array}$ \\
\hline \multicolumn{5}{|l|}{ Individuals settling (n) } \\
\hline Serpulids & 26 & 90 & 41 & 81 \\
\hline Other annelids & 12 & 100 & 1 & 100 \\
\hline Barnacles & 222 & 88 & 313 & 76 \\
\hline Bryozoans (colonies) & 4 & 50 & 1 & 100 \\
\hline Macroalgae & 22 & 77 & 31 & 58 \\
\hline \multicolumn{5}{|l|}{ Space occupied (\%) } \\
\hline Porifera & 3 & 100 & 2 & 100 \\
\hline Coralline algae & 9 & 100 & 5 & 100 \\
\hline
\end{tabular}
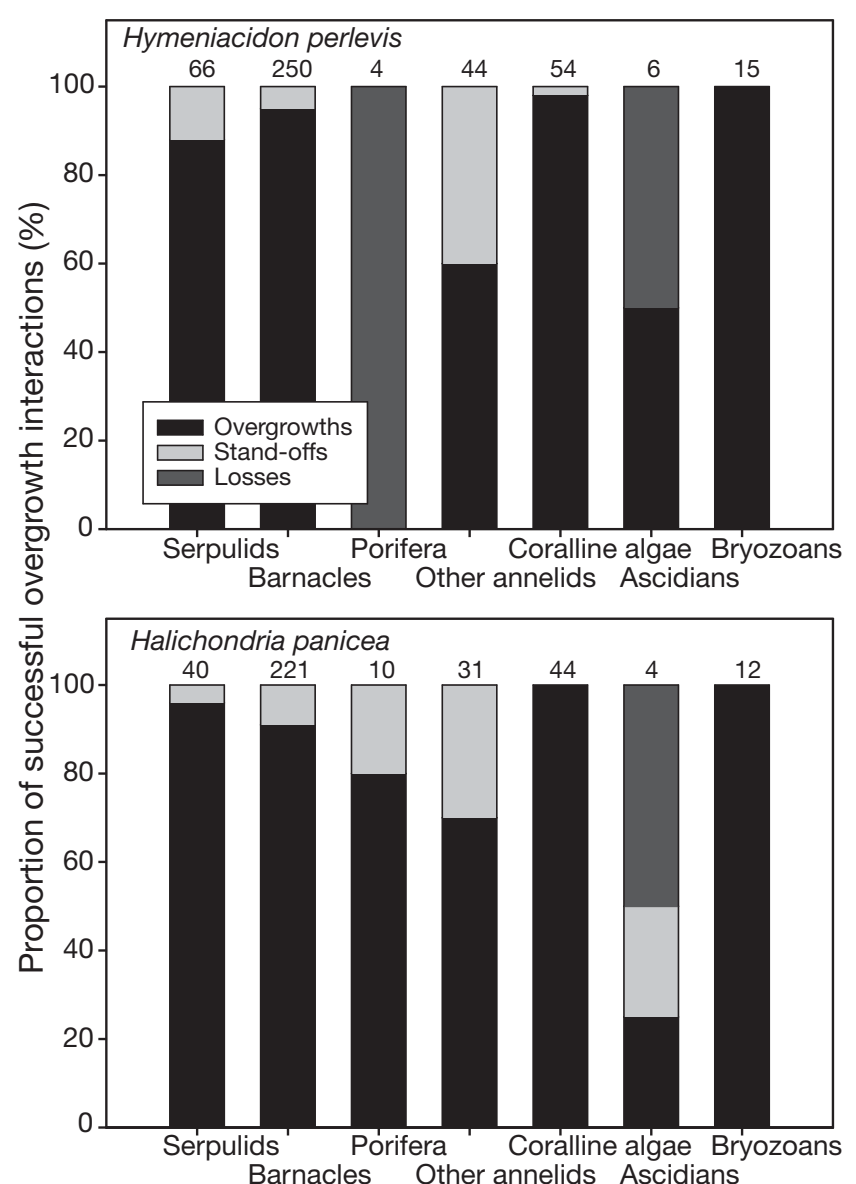

Fig. 3. Halichondria panicea and Hymeniacidon perlevis. Overgrowth, standoff and lost interactions between sponges and other organisms. Successful overgrowth interactions were scored when the feeding aperture or entire organism was overgrown resulting in the death of the losing organism. Interactions were monitored as sponges increased the area they occupied between March and September 2004 and 2005 (data combined from the years) edges of the sponges. Estimations (excluding those specimens which died over the study period) of how much space that was occupied in September 2004 and not reoccupied by the sponges during September 2005 were $23 \%( \pm$ SE 1.7$)$ and $19 \%( \pm$ SE 2.7$)$ for Halichondria panicea and Hymeniacidon perlevis, respectively. Furthermore, in the cases of the sponges that died over the course of the study, $100 \%$ of the space they occupied was released to other organisms.

Table 1 shows the organisms settling or increasing in size to occupy the space previously occupied by sponges in 2004, which was released during sponge tissue contraction over the 2004/2005 winter. Barnacles were the primary organisms ( $\mathrm{n}=250$ and 330 for Halichondria panicea and Hymeniacidon perlevis, respectively) that settled in the area that was not reoccupied by sponges during 2005, with most settlement occurring between April and May (90\%). Serpulids, other annelids and several bryozoans also settled in the newly released space. The majority of these individuals survived from the time of settlement until the end of the observation period in November 2005 (when sponges were again entering contraction periods).

\section{DISCUSSION}

I found that Halichondria panicea and Hymeniacidon perlevis showed marked seasonal growth during spring and summer periods, followed by periods of tissue regression during the autumn and winter. This is consistent with previous studies of sponge population dynamics (e.g. Stone 1970, Barthel 1989, Bell \& Barnes 2002, Koopmans \& Wijffels 2008). During periods of growth both species overgrew (and killed) the majority of organisms they came into contact with, although space was freed during seasonal contraction. This 


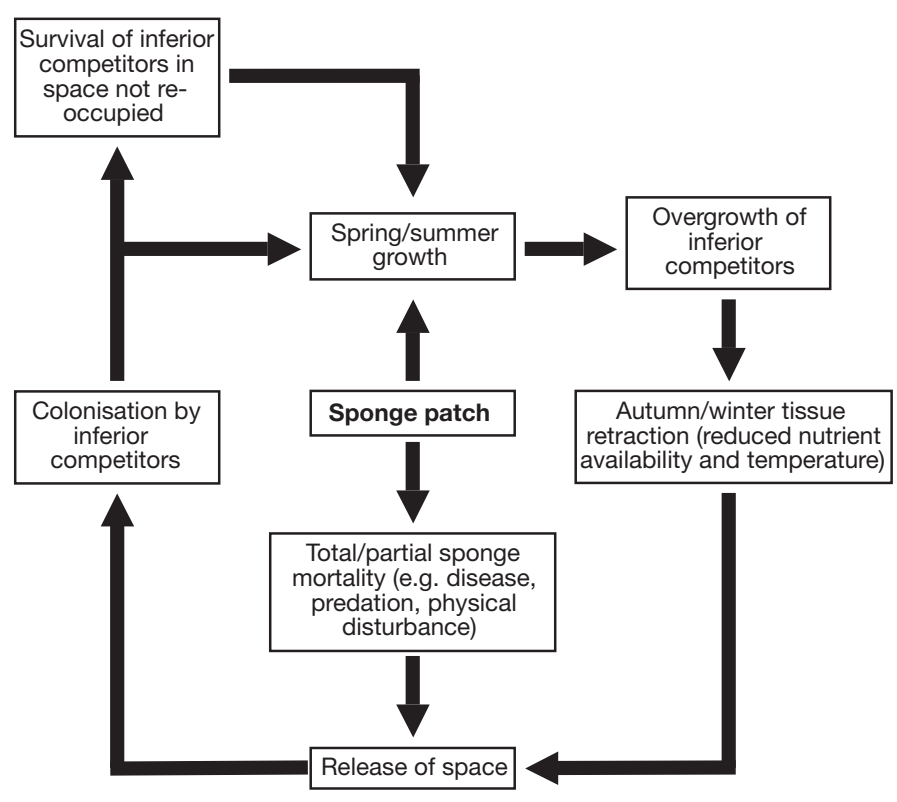

Fig. 4. Sponge disturbance. Conceptual diagram illustrating the role of sponges as agents of biological disturbance

freed space was subsequently colonised by most of the organisms that were overgrown by sponges. Importantly, sponges did not necessarily occupy the same area of rock as they did in the previous year, and growth did not occur uniformly at the edges of sponge patches. This allowed competitively inferior species to persist. On the basis that these 2 species are strong spatial competitors that occupy ca. $18 \%$ of suitable sponge habitat ( 80 to $100 \%$ ) on the local low-tide area (both species combined), and that they only reoccupy ca. $80 \%$ of the space they occupied in the previous year, I have demonstrated that sponges do act as agents of biological disturbance at the site level with an annual turnover of ca. 3 to $4 \%$ of the lower shore space. This pattern of contraction and expansion is most likely being driven by regional-scale seasonality related parameters including temperature and food availability. A conceptual diagram illustrating the role of sponges as agents of biological disturbance is shown in Fig. 4. The abundance of sponges on the shores at the 2 sites used in the present study may be higher than other areas throughout these species' ranges (pers. obs.); however, even in areas with a much lower area occupied by sponges than reported here (e.g. $5 \%$ ), turnover rates are still likely to be $1 \%$ annually. In subtidal environments where sponges are often very abundant ( $>50 \%$ in some places in the UK), these rates may be much higher. These figures only refer to the lower shore ( 0 to $0.3 \mathrm{~m}$ above low-water spring tide mark) intertidal communities, although both Halichondria panicea and Hymeniacidon perlevis are abundant in the shallow subtidal environments at the study sites.

\section{Temporal sponge variability and sponges as agents of disturbance}

Disturbance is widely recognised as a fundamental process structuring biological communities, with the level of disturbance predicted to strongly influence species diversity (Connell 1978). Biological disturbance has been primarily associated with predation, grazing and disease (Paine 1974, Ayling 1981, Wulff 2006b), but the present study has demonstrated how other processes may act locally as agents of disturbance.

Early research on sponge assemblages considered them to be temporarily stable (Pansini \& Pronzato 1990, Pronzato \& Manconi 1995, Garrabou \& Zabala 2001, Corriero et al. 2007). More recently, several authors have described how entire sponge assemblages can be variable over seasonal and annual scales (Bell et al. 2006, Wulff 2006b, Carballo et al. 2008) and that many sponge assemblages may be more dynamic than previously thought. There are in fact a number of other single and multi-species studies that have demonstrated seasonal growth and regression patterns (e.g. Stone 1970, Fell \& Lewandrowski 1981, Duckworth \& Battershill 2001, Koopmans \& Wijffels 2008), while other authors have also reported fast sponge growth rates (e.g. Reiswig 1973, Wilkinson \& Cheshire 1988, Osinga et al. 1999). The evidence for fast growth (or even in the case of slow growth) coupled with seasonal retraction, predation, disease or disturbance-related mortality (e.g. through wave action) means the role of sponges as local-scale agents of biological disturbance may be an important structuring process.

The process of growth and regression of tissues may not be restricted to sponges, as other important competitors, particularly ascidians, may also show seasonal variation in spatial coverage, although not necessarily showing the same patterns as sponges. For example, Turon \& Becerro (1992) found that several species of ascidian in the northwest Mediterranean showed seasonal patterns of growth; however, the pattern of expansion and contraction of tissue showed the reverse patterns to sponges, with increased spatial occupation occurring during winter months.

\section{Population dynamics of Halichondria panicea and Hymeniacidon perlevis}

The population dynamics and growth patterns of Halichondria panicea and Hymeniacidon perlevis may be explained by a number of potential mechanisms. I propose that seasonal variation in the availability of nutrients and/or temperature is the primary explanation for tissue retraction/loss for these 2 sponge species, which is consistent with explanations provided by 
previous authors (Stone 1970, Fell \& Lewandrowski 1981, Duckworth \& Battershill 2001, Garrabou \& Zabala 2001). It has been suggested that periods of tissue retraction may be related to higher energy requirements of sponges compared to other animal groups (Thomassen \& Riisgård 1995). There are, however, still no studies that have experimentally investigated the hypothesis that seasonal change in temperature and/or nutrient/food availability are primarily responsible for seasonal changes in temperate sponges; this is currently a focus of my ongoing research. Furthermore, it remains unknown if the process of tissue retraction is an active response by the sponges to less favourable environmental conditions.

There are also other likely potential sources of passive partial tissue loss that could explain the results of the present study including predation (Knowlton \& Highsmith 2000, 2005), disease (see Webster 2007 for recent review) and physical disturbance. The dorid nudibranch Archidoris pseudoargus is known to feed on Halichondria panicea (Picton \& Morrow 1994), although these were rarely found (4 in total) on sponges when conducting the abundance surveys in March and September. There is no evidence that sponge predation varies seasonally. Generally, nudibranch predation is only thought to cause partial sponge mortality. Previous research on $H$. panicea has shown that sponges regenerate following wounding within ca. 4 wk (Knowlton \& Highsmith 2005). There is no current information on specific predators of Hymeniacidon perlevis. Although in most cases predation is only considered to cause partial sponge mortality, in Alaska Knowlton \& Highsmith (2000) found the overall abundance of $H$. panicea can be controlled and even eliminated by nudibranch predation (from $50 \%$ cover to $0 \%$ ). Such large-scale predation has the potential to free up a large amount of space and release a range of organisms from sponge competition, potentially changing overall community structure (Knowlton \& Highsmith 2000).

Although reports of sponge disease are thought to be increasing, the current data does not necessarily suggest that prevalence is on the increase (Wulff 2007). To my knowledge, there have been no specific reports of natural sponge disease in either of the species examined in the present study, although increased bacterial populations have been induced in the laboratory on Halichondria panicea, which were correlated with increased temperature and decreased flow rates (Hummel et al. 1988). Since these conditions would be expected during summer months, it does not explain my results, as summer was when sponge tissue growth occurred and temperatures are the highest.

Increased physical disturbance has been reported to cause changes in sponge tissues (e.g. Palumbi 1984), with the degree of wave action being found to influence macro (gross shape) and micro (spicule) sponge morphology, with more energy being devoted to inorganic structural components in higher energy environments or conditions. Increased wave action (un-quantified) occurs at both sampling sites during winter months (November to March), as they are typical of Atlantic coast rocky shore communities (pers. obs.). It is therefore possible that tissue rearrangement may occur with greater investment in structural components during winter months or that reducing size makes the sponge more resistant to increased wave action (e.g. drag). Finally, there have also been other reports that seasonal patterns in the area occupied by sponges may be related to reproductive activity, as resources are diverted from somatic tissue to reproductive output (Tanaka 2002), although it seems unlikely that this would explain the patterns I report since reproduction occurs during spring and summer for these species.

The mortality rates reported for Halichondria panicea and Hymeniacidon perlevis in the present study were low (14\% over 2 yr). Fish \& Fish (1996) suggested that $H$. panicea lives for ca. 3 yr; however, evidence from the present study does not support this estimate. Since I reported only ca. $7 \%$ sponge mortality a year, this suggests that $H$. panicea may live for over $15 \mathrm{yr}$. There are no current estimates for the longevity of $H$. perlevis, but my study suggests that, like $H$. panicea, patches may also persist for more than 15 yr. I used sponges that were all similar sizes at the start of the monitoring period, and the age of the sponges prior to the start of the experiment was unknown. Research by Barthel (1989) showed that different-aged $H$. panicea patches grew at different rates, which may explain the high levels of variability between individuals, although this might also be explained by local-scale (metres) environmental variability (e.g. light and flow regime).

\section{Intertidal sponge spatial competition}

Halichondria panicea and Hymeniacidon perlevis are aggressive spatial competitors with the ability to overgrow a range of other species including calcareous algae, annelids, bryozoans, ascidians and barnacles. During the present study I reported intra-phyletic spatial interactions between the 2 sponge species, and in all cases $H$. panicea overgrew $H$. perlevis, although in all of these interactions the overgrown sponge persisted beneath the overgrowing species. The nature of the relationship between these 2 sponge species remains unclear, although both seem to have similar competitive ability relative to other encrusting intertidal species. There have been relatively few studies of 
competitive ability of temperate sponges (but see Ayling 1983, Bell \& Barnes 2003). Ayling (1983) reported sponge-sponge overgrowths, similar to those described here, without any apparent negative effects on the overgrown sponge in a study of subtidal New Zealand sponge assemblages over a 9 mo period, suggesting this may be a defensive mechanism to maintain existing occupied space rather than an aggressive interaction to gain more space. Bell \& Barnes (2003) reported a large number of apparent overgrowths by sponges of other sponges in a study at Lough Hyne, Ireland, where once again the underlying sponges appeared to persist. The nature of such interactions must come at an energetic cost for the sponge that is overgrown, since it is unlikely to be able to pump water as effectively as uncovered areas of the sponge. The inter-phyletic interactions of $H$. panicea and $H$. perlevis support the results of Bell \& Barnes (2003), demonstrating that sponges are one of the top spatial competitors in temperate ecosystems, being overgrown only by ascidians, although their interactions with algae remain controversial (see Bell 2007b). Despite increasing information on temperate sponge competition there is still considerably less information on their competitive ability compared with tropical sponges.

\section{CONCLUSIONS}

The present study demonstrates that sponges can act as important agents of biological disturbance with the 2 species examined in the present study having the ability to turnover space at the rate of 3 to $4 \%$ of the lower shore per annum. The widespread nature of sponges in benthic marine environments, coupled with the short temporal stability reported in many sponge species and assemblages, means this functional role may have been underestimated.

\section{LITERATURE CITED}

Ayling AM (1981) The role of biological disturbance in temperate subtidal encrusting communities. Ecology 62: 830-847

Ayling AM (1983) Factors affecting the spatial distributions of thinly encrusting sponges from temperate waters. Oecologia 60:412-418

Barthel D (1989) Growth of the sponge Halichondria panicea in the North Sea habitat. Proc 21st Eur Mar Biol Symp, 14-19 September 1986, Gdansk, p 23-30

Bell JJ (2007a) Contrasting patterns of species and functional composition of coral reef sponge assemblages. Mar Ecol Prog Ser 339:73-81

Bell JJ (2007b) The ecology of sponges at Lough Hyne Marine Nature Reserve; past, present and future perspectives. J Mar Biol Assoc UK 87:1655-1668
Bell JJ (2008) Functional roles of marine sponges. Estuar Coast Shelf Sci 79:341-353

Bell JJ, Barnes DKA (2002) Unattached sponges: density, distribution and decline. Sarsia 87:110-118

Bell JJ, Barnes DKA (2003) The importance of competitor identity, morphology and ranking methodology to outcomes in interference competition: an example of sponges. Mar Biol 143:415-426

Bell JJ, Carballo JL (2008) Patterns of sponge biodiversity and abundance across different biogeographic regions. Mar Biol (in press)

Bell JJ, Burton M, Bullimore B, Newman PB, Lock K (2006) Morphological monitoring of subtidal sponge assemblages. Mar Ecol Prog Ser 311:79-91

Carballo JL, Vega C, Cruz-Barraza JA, Yáñez B, Nava H, Avila $\mathrm{E}$ (in press) Short and long-term patterns of sponge diversity in rocky tropical coast: evidence of large-scale structuring factors. PSZN I: Mar Ecol 29:216-236

Connell JH (1978) Diversity in tropical rain forests and coral reefs-high diversity of trees and corals is only maintained in a non-equilibrium state. Science 199:1302-1310

Corredor JE, Wilkinson CR, Vincente VP, Morell JM, Otero E (1988) Nitrate release by Caribbean reef sponges. Limnol Oceanogr 33:114-120

Corriero G, Longo C, Mercurio M, Marchini A, Occhipinti-Ambrogi A (2007) Porifera and Bryozoa on artificial hard bottoms in the Venice Lagoon: spatial distribution and temporal changes in the northern basin. Ital J Zool 74:21-29

Diaz MC, Rützler K (2001) Sponges: an essential component of Caribbean coral reefs. Bull Mar Sci 69:535-546

Duckworth AR, Battershill CR (2001) Population dynamics and chemical ecology of New Zealand Demospongiae Latrunculia sp. nov and Polymastia croceus (Poecilosclerida: Latrunculiidae: Polymastiidae). N Z J Mar Freshw Res 35:935-949

> Fell PE, Lewandrowski KB (1981) Population dynamics of the estuarine sponge, Halichondria sp., within a New England eelgrass community. J Exp Mar Biol Ecol 55:49-63

Fish JD, Fish S (1996) A student's guide to the seashore, 2nd edn. Cambridge University Press, Cambridge

> Garrabou J, Zabala M (2001) Growth dynamics in four Mediterranean demosponges. Estuar Coast Shelf Sci 52:293-303

> Goreau TF, Hartman WD (1966) Sponge: effect on the form of coral reefs. Science 151:343-344

> Hummel H, Sepers ABJ, de Wolf L, Melissen FW (1988) Bacterial growth of the marine sponge Halichondria panicea induced by reduced water flow rate. Mar Ecol Prog Ser 42: 195-198

- Knowlton AL, Highsmith RC (2000) Convergence in the space-time continuum: a predator-prey interaction. Mar Ecol Prog Ser 197:285-291

> Knowlton AL, Highsmith RC (2005) Nudibranch-sponge feeding dynamics: benefits of symbiont-containing sponge to Archidoris montereyensis (Cooper, 1862) and recovery of nudibranch feeding scars by Halichondria panicea (Pallas, 1766). J Exp Mar Biol Ecol 327:36-46

> Koopmans M, Wijffels RH (2008) Seasonal growth rate of the sponge Haliclona oculata (Demospongiae: Haplosclerida). Mar Biotechnol 10:502-510

Lewis JR (1964) The ecology of rocky shores. English Universities Press, London

Osinga R, de Beukelaer PB, Meijer EM, Tramper J, Wijffels $\mathrm{RH}$ (1999) Growth of the sponge Pseudosuberities (aff.) andrewsi in a closed system. J Biotechnol 70:155-161

Paine RT (1974) Intertidal community structure: experimental studies on the relationship between a dominant competitor and its principal predator. Oecologia 15:93-120 
Palumbi SR (1984) Tactics of acclimation-morphological changes of sponges in an unpredictable environment. Science 225:1478-1480

Pansini M, Pronzato R (1990) Observations on the dynamics of a Mediterranean sponge community. In: Rützler K (ed) New perspectives in sponge biology. Smithsonian Institution Press, Washington, DC, p 404-415

Picton BE, Morrow CC (1994) A field guide to the nudibranchs of the British Isles. Immel Publishing, London

Pronzato R, Manconi R (1995) Long-term dynamics of a freshwater sponge population. Freshw Biol 33:485-495

Reiswig HM (1971) Particle feeding in natural populations of three marine demosponges. Biol Bull (Woods Hole) 141: 568-591

Reiswig HM (1973) Population dynamics of three Jamaican demonspongiae. Bull Mar Sci 23:191-226

Ribeiro SM, Omena EP, Muricy G (2003) Macrofauna associated to Mycale microsigmatosa (Porifera, Demospongiae) in Rio de Janeiro State, SE Brazil. Estuar Coast Shelf Sci 57:951-959

Rützler K (1975) The role of burrowing sponges in bioerosion. Oecologia 19:203-219

Sousa ME (1979) Experimental investigation of disturbance and ecological succession in a rocky intertidal algal community. Ecol Monogr 49:227-254

Stone AR (1970) Growth and reproduction of Hymeniacidon perleve (Montagu) (Porifera) in Langstone Harbour, Hampshire. J Zool 161:443-459

Editorial responsibility: Roger Hughes,

Bangor, UK
Tanaka K (2002) Growth dynamics and mortality of the intertidal encrusting sponge Halichondria okadai (Demospongiae, Halichondrida). Mar Biol 140:383-389

> Thomassen S, Riisgård HU (1995) Growth and energetics of the sponge Halichondria panicea. Mar Ecol Prog Ser 128: $239-246$

> Turon X, Becerro MA (1992) Growth and survival of several ascidian species from the northwestern Mediterranean. Mar Ecol Prog Ser 82:235-247

Webster NS (2007) Sponge disease: a global threat? Environ Microbiol 9:1363-1375

Wilkinson CR (1983) Net primary productivity in coral reef sponges. Science 219:410-412

> Wilkinson CR, Cheshire AC (1988) Growth rates of Jamaican coral reef sponges after Hurricane Allen. Biol Bull (Woods Hole) 175:175-179

Wulff JL (2001) Assessing and monitoring coral reef sponges: why and how? Bull Mar Sci 69:831-846

Wulff JL (2006a) Ecological interactions of marine sponges. Can J Zool 84:146-166

Wulff JL (2006b) Rapid diversity and abundance decline in a Caribbean coral reef sponge community. Biol Conserv 127:167-176

Wulff JL (2007) Disease prevalence and population density over time in three common Caribbean coral reef sponge species. J Mar Biol Assoc UK 87:1715-1720

Wulff JL, Buss LW (1979) Do sponges help hold coral reefs together? Nature 281:474-475

Submitted: April 2, 2008; Accepted: July 3, 2008

Proofs received from author(s): September 10, 2008 